\title{
THE MORALS OF ECONOMIC INTERNATIONALISM
}





\title{
THE MORALS OF ECONOMIC INTERNATIONALISM
}

\author{
BY \\ J. A. HOBSON \\ AUTHOR OF "THE INDUSTRIAL SYSTEM," "THE EVOLUTION \\ OF MODERN CAPITALISM," "WORK AND WEALTh," ETC.
}

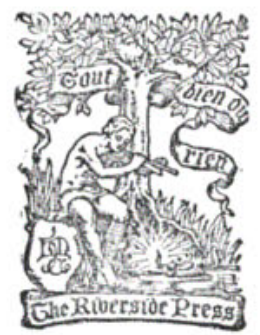

BOSTON AND NEW YORK
HOUGHTON MIFFLIN COMPANY

otbe mibersibe press Tambribge

I920 
COPYRIGHT, 1920, BY THE REGENTS OF THE UNIVERSITY OY CALIFORNIA

ALL RIGHTS KESERVED 